\title{
FORMULASI PANGAN DARURAT BERBENTUK FOOD BARS BERBASIS TEPUNG MILLET PUTIH (Panicum milliaceum L.) DAN TEPUNG KACANG MERAH (Phaseolus vulgaris $L$.)
}

\author{
Formulation of Food Bars Made from White Millet Flour (Panicum milliaceum L) and Red Bean Flour \\ (Phaseolus vulgaris L)
}

\author{
Raden Baskara Katri Anandito, Siswanti, Edhi Nurhartadi, Rini Hapsari \\ Program Studi Ilmu dan Teknologi Pangan, Fakultas Pertanian, Universitas Sebelas Maret, \\ Jl. Ir. Sutami 36A, Kentingan, Surakarta 57126 \\ Email: anandito_ito@yahoo.com
}

\begin{abstract}
ABSTRAK
Penelitian ini bertujuan untuk memperoleh formula pangan darurat berbentuk food bars berbahan dasar tepung millet putih dan tepung kacang merah. Food bars dibuat dengan teknologi Intermediate Moisture Food (IMF) dengan teknik pencelupan basah. Penelitian ini menggunakan Rancangan Acak Lengkap (RAL) yang terdiri dari satu faktor yaitu variasi formula tepung millet putih dan tepung kacang merah $(15: 10 ; 12,5: 12,5 ; 10: 15)$. Hasil penelitian menunjukkan bahwa formula food bars dengan tingkat penerimaan konsumen tertinggi pada komposisi tepung millet putih $15 \mathrm{~g}$, tepung kacang merah $10 \mathrm{~g}$, gula halus $2 \mathrm{~g}$, margarine $10 \mathrm{~g}$, susu full cream $13 \mathrm{~g}$, dan penambahan air $6,043 \mathrm{~g}$. Dalam 100 $\mathrm{g}$ food bars terkandung air, abu, protein, lemak, karbohidrat, nilai $\mathrm{a}_{\mathrm{w}}$ dan kalori berturut-turut sebesar $16,45 \%, 1,45 \%$, $10,99 \%, 35,39 \%, 42,26 \%, 0,81$ dan $233,80 \mathrm{kkal} / \mathrm{bar}$.
\end{abstract}

Kata kunci: Food bars, pangan darurat, tepung kacang merah, tepung millet putih

\begin{abstract}
This study aimed to obtain a formula emergency food in the form food bars made from white millet flour and red bean flour. Foodbars made with Intermediate Moisture Food (IMF) technology with wet dyeing technique. This study used completely randomized design (CRD), which consists of a single factor, namely the variation formula white millet flour and red bean flour. The results showed that the formula food bars with the highest level of consumer acceptance in the composition of $15 \mathrm{~g}$ of white millet flour, red bean flour $10 \mathrm{~g}, 2 \mathrm{~g}$ sugar, $10 \mathrm{~g}$ margarine, milk full cream $13 \mathrm{~g}, 6.043$ $\mathrm{g}$ and the addition of water. In $100 \mathrm{~g}$ of food bars contained water, ash, protein, fat, carbohydrate, and caloric value $\mathrm{a}_{\mathrm{w}}$ respectively of $16.45 \%, 1.45 \%, 10.99 \%, 35.39 \%, 42.26 \%, 0,81$ and $233.80 \mathrm{kcal} / \mathrm{bar}$.
\end{abstract}

Keywords: Emergency food, food bars, red bean flour, white millet flour

\section{PENDAHULUAN}

Topografi wilayah Indonesia memiliki tingkat kerawanan terhadap bencana alam dengan intensitas yang cukup tinggi. Bencana alam yang terjadi pada di beberapa daerah di Indonesia menyebabkan banyak korban mengungsi dan tinggal di tempat-tempat darurat. Menurut data BNPB (2014), sejak tahun 1988 sampai pertengahan 2003 jumlah bencana di Indonesia mencapai 647 bencana alam meliputi banjir, longsor, gempa bumi, dan angin topan, dengan jumlah korban jiwa sebanyak 2022. Pada tahun 2002, tercatat tidak kurang dari 14 bencana alam terjadi terutama banjir dan tanah longsor. Bencana tersebut menyebabkan lebih dari 101 orang meninggal. Pertengahan tahun 2003 sampai pertengahan 2004 terjadi ratusan bencana dan mengakibatkan hampir 1000 korban jiwa. Tahun 2012 hingga pertengahan 2014, longsor terjadi 705 kali menyebabkan korban tewas 369 dan 16.332 luka. Sepanjang 2012 longsor terjadi 291 kali, tahun 2013 ada 296 kali, dan hingga Juni 2014 terjadi 118 kali Selama 2014, data sementara yang dihimpun BNPB, telah terjadi 182 kejadian bencana hidrometeorologi seperti banjir, longsor, dan puting beliung. Akibatnya, sebanyak 137 orang tewas, 1,1 juta 
jiwa mengungsi dan menderita. Dalam kondisi serba darurat, salah satu bantuan yang sangat dibutuhkan korban bencana adalah makanan. Kondisi serba darurat, salah satu bantuan yang sangat dibutuhkan korban bencana adalah makanan siap santap (ready to eat) agar mudah mengkonsumsinya.

Pangan darurat yang ideal diberikan seharusnya mengandung zat gizi yang cukup, tidak hanya mengenyangkan tetapi juga mengandung kalori sesuai dengan angka kecukupan gizi (AKG), yaitu $2.100 \mathrm{kkal} /$ hari (Institute of Medicine, 1995). Menurut Zoumas dkk. (2002) untuk mencapai total kalori tersebut, jumlah makronutrien yang direkomendasikan kandungan protein, lemak, dan karbohidrat berturut-turut sebesar 10-15\%, 35-45 \%, dan karbohidrat 40-50 \%. Salah satu produk pangan yang berpotensi untuk dikembangkan sebagai pangan darurat adalah pangan semi basah atau Intermediate Moisture Food (IMF). Menurut Soekarto (1979), pangan semi basah memiliki kriteria kadar air sebesar $10-40 \%$ dan aktivitas air $\left(\mathrm{a}_{\mathrm{w}}\right)$ 0,6-0,9. Menurut Widjanarko (2008), food bars dibuat dari campuran bahan pangan yang diperkaya dengan nutrisi yang kemudian dibentuk menjadi bentuk padat dan kompak. Food bars lebih tahan terhadap tekanan daripada produk pangan kering karena termasuk produk pangan semi basah yang dapat diproduksi dengan cara tradisional dan modern.

Indonesia kaya akan sumber bahan pangan baik umbiumbian maupun serealia. Salah satu bahan pangan lokal yang dapat dimanfaatkan sebagai bahan subtitusi gandum pada pembuatan food bars adalah millet. Millet memiliki nilai kandungan gizi yang mirip dengan tanaman pangan lainnya seperti padi, jagung, gandum, dan tanaman biji-bijian yang lain karena tanaman millet sendiri adalah tergolong ke dalam jenis tanaman biji-bijian (Marlin, 2009).

Varietas millet yang digunakan dalam penelitian ini adalah millet putih dengan jenis proso millet. Millet termasuk tanaman serealia ekonomi keempat setelah padi, gandum, dan jagung. Biji millet mengandung karbohidrat dan protein yang tidak kalah dengan beras. Kandungan gizi pada tepung milet putih adalah air, abu, lemak, protein, pati, karbohidrat dan serat kasar berturut-turut sebesar 9,19\%, 1,80\%, 2,58\%, 11,29\%, 56,53\%, 74,52\% dan 2,01\% (Prabowo, 2010).

Tepung kacang merah digunakan sebagai sumber protein. Kacang merah (Phaseolus vulgaris L) terkenal sebagai sumber protein nabati. Protein pada kacang merah memiliki kandungan yang tinggi berkisar antara 16-20\%, biji kacang merah juga sumber mineral, dan vitamin (Astawan, 2009). Dalam penelitian ini digunakan tepung kacang merah pratanak. Proses pratanak diharapkan tidak hanya mampu mengurangi waktu pemasakan dan meningkatkan sifat organoleptik saja tetapi juga berpengaruh pada sifat fungsional kacang merah sebagai bahan pangan seperti meningkatnya avaibilitas zat gizi dan menurunkan indeks glisemik. Proses pratanak memudahkan dalam proses penyajian dan berpotensi baik untuk menghambat gejala-gejala penyakit diabetes (Anonim, 1996). Kandungan gizi kacang merah pratanak adalah: kadar air 9,33\%, protein 19,82\%, lemak 1,55\%, kadar abu 4,31\% dan karbohidrat 69,51\% (Siswanti dan Ariyantoro, 2012). Menurut US Agency of International Development (USAID), pangan darurat hendaknya dapat digunakan dengan layak sampai minimum 15 hari dari mulai diproduksi. Tujuan dari penelitian ini adalah untuk memperoleh formula pangan darurat berbentuk food bars berbahan dasar tepung millet putih dan tepung kacang merah.

\section{METODE PENELITIAN}

\section{Waktu dan Tempat Penelitian}

Penelitian ini dilaksanakan di Laboratorium Rekayasa Proses Pengolahan dan Hasil Pertanian Fakultas Pertanian Universitas Sebelas Maret Surakarta dan Laboratorium Biokimia PAU Pangan dan Gizi Universitas Gadjah Mada Yogyakarta.

\section{Bahan dan Alat}

Bahan yang digunakan dalam penelitian pembuatan food bars ini adalah millet putih (Panicum milliaceum L.) dan kacang merah (Phaseolus vulgaris L.) yang diperoleh dari Pasar Legi Surakarta. Bahan tambahan yang dibutuhkan yaitu gula, susu full cream, margarin dan air. Bahan kimia yang digunakan adalah $\mathrm{H}_{2} \mathrm{SO}_{4}$ pekat, $\mathrm{NaOH} 50 \%, \mathrm{HCl} 0,02$ $\mathrm{N}$, indikator mengsel (campuran metil merah $0,02 \%$ dalam alkohol dan metil biru 0,02\% dalam alkohol (2:1), dan $\mathrm{NaOH} 0,02 \mathrm{~N}$ untuk analisa kadar protein; petroleum eter untuk pelarut analisa kadar lemak, dan garam-garam $\mathrm{MgCl}_{2}$, $\mathrm{K}_{2} \mathrm{CO}_{3}, \mathrm{NaNO}_{2}, \mathrm{LiCl}$ dan $\mathrm{KCl}$ untuk analisa sifat isoterm sorpsi lembab.

Peralatan yang digunakan dalam penelitian ini adalah alat-alat pembuat tepung millet kuning yaitu huller, grinder, ayakan 80 dan 50 mesh, baskom, alat penampi, cabinet dryer, autoklaf, timbangan analitik, oven dan loyang pencetak, serta peralatan untuk analisa kadar air, abu, lemak, protein, kalori (bomb calorimeter) dan sifat ISL (Isoterm Sorpsi Lembab).

\section{Tahapan Penelitian}

Alur kegiatan tahapan penelitian yang dilakukan adalah sebagai berikut:

Pembuatan tepung millet putih. Biji millet putih dihilangkan kulit arinya menggunakan huller, kemudian kulit ari dan kotoran dipisahkan dengan cara ditampi. Setelah itu dilakukan pengecilan ukuran dengan mesin penepung dan pengayakan sehingga diperoleh ukuran tepung 80 mesh. 
Pembuatan tepung kacang merah pratanak (Marsono, dkk., 2003). Kacang merah direndam dalam larutan natrium bikarbonat selama 4 jam. Proses perendaman ini berfungsi membuat tekstur produk menjadi lembut, mengurangi waktu pemasakan dan meminimalkan kehilangan zat gizi dari produk. Selesai perendaman dilanjutkan pencucian dengan akuades. Kacang merah yang sudah ditiriskan dilakukan pemanasan menggunakan autoklaf pada suhu $121^{\circ} \mathrm{C}$ selama 2 menit. Pengeringan menggunakan cabinet dryer pada suhu $55{ }^{\circ} \mathrm{C}$ selama \pm 18 jam. Setelah selesai pengeringan dilanjutkan penepungan dan pengayakan sehingga diperoleh ukuran tepung 50 mesh.

Isoterm sorpsi lembab. Bahan yang digunakan dalam pembuatan food bars seperti tepung kacang merah, millet putih, gula dan full cream dicampur menjadi satu hingga homogen. Sebanyak 1-2 g sampel adonan dimasukkan dalam cawan alumunium, dan dikeringkan dengan menggunakan oven sampai berat sampel konstan. Selanjutnya sampel dimasukkan ke dalam masing-masing toples kaca yang telah berisi larutan garam jenuh. Jenis garam yang digunakan antara lain: $\mathrm{MgCl}_{2}, \mathrm{~K}_{2} \mathrm{CO}_{3}, \mathrm{NaNO}_{2}, \mathrm{LiCl}$ dan $\mathrm{KCl}$. Sampel dibiarkan selama satu minggu, kemudian ditimbang hingga berat konstan. Skema pengujian isoterm sorpsi lembab (ISL) dapat dilihat pada Gambar 1.

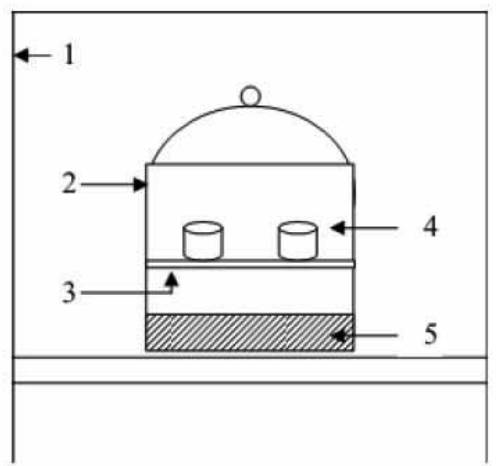

Keterangan :

1.Inkubator

2.Toples kedap udara

3.Penyangga

4.Cawan alumunium

5.Larutan garam jenuh

Gambar 1. Skema pengujian alat uji isoterm sorpsi lembab

Pembuatan food bars. Bahan yang digunakan dalam pembuatan food bars seperti tepung kacang merah pratanak, tepung millet putih, gula, margarin, full cream bubuk dicampur kemudian ditambahkan air dan diaduk hingga rata. Adonan dicetak pada loyang dan dilakukan pemasakan menggunakan oven pada suhu $120^{\circ} \mathrm{C}$ selama 45 menit.

\section{Analisis}

Analisis yang digunakan dalam penelitian meliputi kadar air dengan metode Termogravimetri (AOAC, 2000), kadar lemak dengan metode ekstraksi Soxhlet (AOAC, 2000), kadar abu dengan metode pengabuan kering (AOAC, 2000), kadar protein dengan metode mikro-Kjeldahl (AOAC, 2000), kadar karbohidrat by difference (AOAC, 2000), aktivitas air dengan $\mathrm{a}_{\mathrm{w}}$ meter (Apriyantono dkk., 1989), sifat sensoris dengan metode uji kesukaan (Setyaningsih dkk., 2010), nilai kalori dengan bomb calorimeter, sifat Isoterm Sorpsi Lembab (ISL) dengan metode Termogravimetri Statis (Labuza, 1984).

\section{Formulasi Food Bars}

Adapun formulasi food bars yang dilakukan dapat dilihat pada Tabel 1 .

Tabel 1. Formulasi food bars

\begin{tabular}{lccc}
\hline \multirow{2}{*}{ Bahan } & \multicolumn{3}{c}{ Total berat bahan / 50 g } \\
\cline { 2 - 4 } & Formulasi 1 & Formulasi 2 & Formulasi 3 \\
\hline Tepung millet putih & 15 & 12,5 & 10 \\
Tepung kacang merah & 10 & 12,5 & 15 \\
pratanak & & & \\
Susu bubuk full cream & 13 & 13 & 13 \\
Gula & 2 & 2 & 2 \\
Margarin & 10 & 10 & 10 \\
\hline
\end{tabular}

\section{Rancangan Percobaan}

Rancangan percobaan yang digunakan dalam penelitian ini adalah Rancangan Acak Lengkap (RAL) dengan satu faktor yaitu variasi komposisi tepung millet putih dan tepung kacang merah sebagai bahan dasar pembuatan food bars. Data analisis sensoris yang diperoleh dianalisis statistik dengan metode one way ANOVA. Jika menunjukkan perbedaan yang signifikan maka dilanjutkan dengan uji beda nyata menggunakan analisis Duncan's Multiple Range Test (DMRT) pada taraf signifikansi $\alpha=0,05$.

\section{HASIL DAN PEMBAHASAN}

\section{Penentuan Komposisi Formulasi Awal Food Bars}

Nilai gizi makronutrien masing-masing bahan penyusun food bars penting diketahui sebelum dilakukan formulasi produk. Nilai gizi makronutrien penyusun food bars dapat dilihat pada Tabel 2.

Formulasi produk pangan darurat menggunakan prinsip kesetimbangan massa. Prinsip kesetimbangan adalah setiap bahan yang masuk (input) harus memiliki jumlah yang setara dengan akumulasi selama proses dan bahan yang keluar atau dihasilkan (output). Nilai kalori total didapatkan dari jumlah makronutrien bahan yang digunakan dikalikan dengan nilai kalori masing-masing. Protein memiliki nilai energi sebesar $4 \mathrm{kkal} / \mathrm{g}$, lemak $9 \mathrm{kkal} / \mathrm{g}$, dan karbohidrat 4 kkal/g. Prediksi kecukupan gizi terdapat pada Tabel 3. 
Tabel 2. Nilai gizi makronutrien penyusun food bars yang digunakan dalam formulasi

\begin{tabular}{llll}
\hline \multirow{2}{*}{ Bahan } & \multicolumn{3}{l}{ Makronutrien $(\mathrm{g} / 100 \mathrm{~g}$ bobot solid $)$} \\
\cline { 2 - 4 } & Protein & Lemak & Karbohidrat \\
\hline Millet putih $^{\mathrm{a}}$ & 11,29 & 2,58 & 74,52 \\
Kacang merah pratanak $^{\mathrm{b}}$ & 17,97 & 1,41 & 63,02 \\
Susu bubuk full cream $^{\mathrm{c}}$ & 27 & 26 & 40 \\
Gula $^{\mathrm{d}}$ & 0 & 0 & 94 \\
Margarin $^{\mathrm{d}}$ & 0,6 & 81 & 0,4 \\
\hline
\end{tabular}

Keterangan: ${ }^{\mathrm{a}}=$ berdasarkan Prabowo (2010)

$\mathrm{b}=$ berdasarkan Siswanti dan Ariyantoro (2012)

$\mathrm{c}=$ berdasarkan data pada label kemasan produk

$\mathrm{d}=$ berdasarkan data DKBM dengan konversi bobot solidnya

Tabel 3. Prediksi kecukupan gizi berdasarkan formulasi food bars

\begin{tabular}{lcccc}
\hline \multirow{2}{*}{ Komposisi } & \multicolumn{3}{c}{ Sumbangan kalori (\%) } & \multirow{2}{*}{ Standar } \\
\cline { 2 - 4 } & F1 & F2 & F3 & pangan darurat \\
\hline Karbohidrat & 41,925 & 41,567 & 41,207 & $40-45$ \\
Lemak & 46,043 & 46,077 & 46,111 & $35-45$ \\
Protein & 12,033 & 12,357 & 12,683 & $10-15$ \\
\hline Total kalori (kkal) & 234,712 & 233,966 & & 233 \\
\hline
\end{tabular}

Tabel 2 menunjukkan bahwa ketiga formulasi memiliki perbedaan komposisi pada bahan tepung millet putih dan tepung kacang merah pratanak. Perbandingan tepung millet putih dengan tepung kacang merah pratanak pada formulasi 1 yaitu 60:40, formulasi 2 yaitu 50:50 dan formulasi 3 yaitu 40:60.

Menurut Zoumas dkk. (2002), total kalori yang direkomendasi untuk produk pangan darurat adalah 2100 kkal, jika 1 food bars mengandung 233 kkal maka diperlukan 9 food bars untuk memenuhi setara jumlah total kalori yang direkomendasikan. Tabel 3 menunjukkan bahwa prediksi kalori food bars pada formulasi 1, 2 dan 3 berturut-turut sebesar 234,712; 233,966 dan 233,221. Nilai kalori tersebut memenuhi angka kecukupan gizi untuk pangan darurat.

\section{Penentuan Kurva Isoterm Sorpsi Lembab Formula Awal Food Bars}

Penentuan kurva isoterm sorpsi lembab bertujuan untuk mengetahui jumlah air yang ditambahkan pada formulasi 1, 2 dan 3 sesuai nilai $\mathrm{a}_{\mathrm{w}}$ antara 0,8-0,9. Penentuan kurva isoterm diawali dengan penentuan kadar air kesetimbangan pada berbagai RH pada suhu ruang.

Penentuan kurva isoterm sorpsi ini menggunakan 5 jenis larutan garam jenuh. Data hubungan antara $a_{w}$ dengan kadar air seimbang dapat dilihat pada Tabel 4.
Tabel 4. Data hubungan antara $\mathrm{a}_{\mathrm{w}}$ dan kadar air seimbang

\begin{tabular}{llccc}
\hline \multirow{2}{*}{ Garam } & \multirow{2}{*}{$\mathrm{a}_{\mathrm{w}}$} & \multicolumn{3}{c}{ Kadar air seimbang } \\
\cline { 3 - 5 } & & Formulasi 1 & Formulasi 2 & Formulasi 3 \\
\hline $\mathrm{LiCl}$ & 0,113 & 5,5856 & 4,8592 & 5,7227 \\
$\mathrm{MgCl}_{2}$ & 0,321 & 8,6476 & 9,0217 & 5,785 \\
$\mathrm{~K}_{2} \mathrm{CO}_{3}$ & 0,436 & 7,944 & 8,2657 & 7,8542 \\
$\mathrm{NaNO}_{2}$ & 0,628 & 10,3593 & 10,2737 & 10,6294 \\
$\mathrm{KCl}$ & 0,83 & 15,4842 & 16,3386 & 15,0492 \\
\hline
\end{tabular}

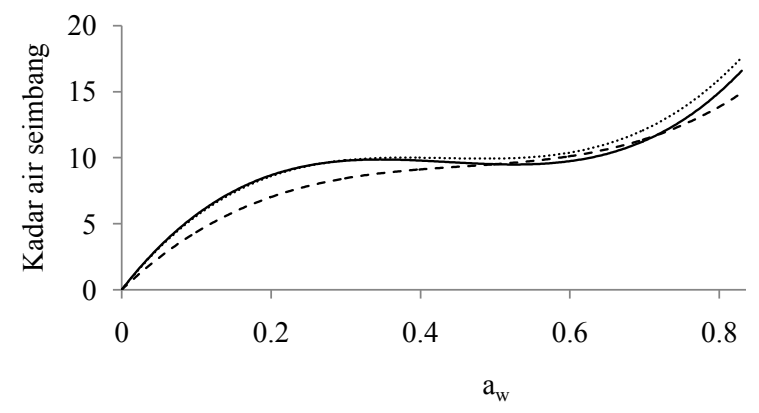

- formula $1 \quad$............... formula $2 \quad$ - - - formula

Gambar 2. Kurva isoterm sorpsi lembab (ISL) pada food bars formulasi 1, 2 dan 3.

Berdasarkan Gambar 2 menunjukkan bahwa klasifikasi kurva ISL menurut sifat bahan membentuk kurva seperti huruf $\mathrm{S}$ (sigmoid) pada food bars berbahan dasar tepung millet putih dan tepung kacang merah. Sesuai pendapat Labuza (1984) menyatakan bahwa bahan makanan serealia dan makanan kering mempunyai kurva ISL berbentuk sigmoid. Gambar 2 dan Gambar 3 yang mengindikasikan adanya perubahan sifat fisika-kimia pengikatan air oleh bahan. Lengkungan pertama pada $\mathrm{a}_{\mathrm{w}} \pm 0,2-0,4$ menunjukkan batas air terikat primer dan lengkungan kedua pada $\mathrm{a}_{\mathrm{w}} \pm 0,6-0,7$ menunjukkan batas air terikat sekunder.

Kurva ISL dapat menunjukkan fraksi air terkandung dalam bahan makanan. Terdapat tiga fraksi air terikat primer, sekunder dan tersier. Ketiga fraksi tersebut menunjukkan ketahanan bahan pangan terhadap kerusakan akibat mikroorganisme. Air terikat primer atau air terikat lapis tunggal terletak pada $\mathrm{a}_{\mathrm{w}}<0,25$, air terikat sekunder terletak $\mathrm{a}_{\mathrm{w}}$ 0,25-0,75 dan air terikat sekunder terletak pada $\mathrm{a}_{\mathrm{w}}>0,75$ (Suyitno, 1995).

Berdasarkan data hubungan kadar air (M) dengan nilai $a_{w}$ pada kurva isoterm sorpsi maka dibuat persamaan matematis model GAB (Guggenheim Anderson de Boer) adalah sebagai berikut:

Keterangan: $\quad \mathrm{M}=$ kadar air

$$
\mathrm{M}=\frac{\mathrm{C} \cdot \mathrm{k} \cdot \mathrm{Mo} \cdot \mathrm{a}_{\mathrm{w}}}{\left(1-\mathrm{k} \cdot \mathrm{a}_{\mathrm{w}}\right)\left(1-\mathrm{k} \cdot \mathrm{a}_{\mathrm{w}}+\mathrm{C} \cdot \mathrm{k} \cdot \mathrm{a}_{\mathrm{w}}\right)}
$$

$\mathrm{Mo}=$ kadar air monolayer

$\mathrm{a}_{\mathrm{w}}=$ aktivitas air

$\mathrm{C}$ dan k konstanta persamaan GAB. 
Kurva isoterm sorpsi lembab dengan model persamaan GAB selanjutnya menjadi persamaan polinomial ordo dua atau persamaan kuadratiknya dengan membuat plot $\mathrm{a}_{\mathrm{w}} / \mathrm{M}$ sebagai ordinat dan $\mathrm{a}_{\mathrm{w}}$ sebagai absis. Kurva isoterm sorpsi lembab model persamaan GAB ditunjukkan pada Gambar 3.

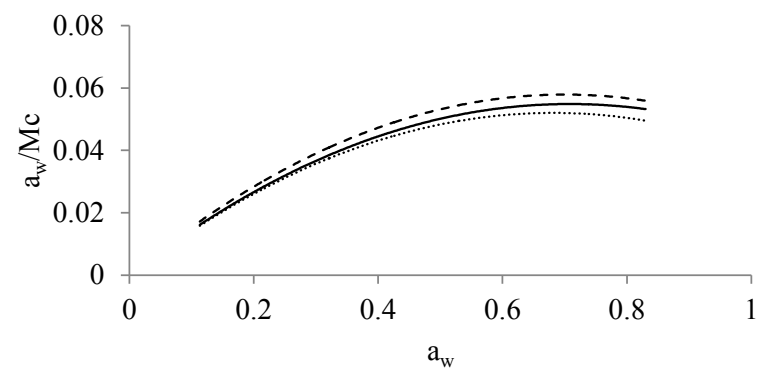

— formula $1 \quad$............... formula $2 \quad$ - - - formula 3

Gambar 3. Kurva isoterm sorpsi lembab dalam persamaan GAB

Berdasarkan Gambar 3 maka diperoleh nilai konstanta $\mathrm{C}$ dan $\mathrm{k}$ serta nilai kadar air monolayer (Mo). Nilai-nilai tersebut dapat digunakan untuk menentukan kadar air basis kering (M), sehngga dapat ditentukan jumlah air yang ditambahkan dalam proses pembuatan food bars.

Hasil nilai k, C, Mo dari persamaan kuadratik dapat dilihat pada Tabel 5 .

Tabel 5. Hasil nilai k, C, Mo dari persamaan kuadratik

\begin{tabular}{lccc}
\hline & F1 & F2 & F3 \\
\hline $\mathrm{k}$ & 0,711657 & 0,735379 & 0,696042 \\
$\mathrm{C}$ & 106,2359 & 184,9847 & 108,7259 \\
Mo & 5,958064 & 6,272277 & 6,29234 \\
$\mathrm{M}$ & 16,4857 & 18,4972 & 16,7523 \\
\hline
\end{tabular}

\section{Penentuan Jumlah Air yang Ditambahkan}

Penambahan air diharapkan nilai $\mathrm{a}_{\mathrm{w}}$ food bars antara 0,8-0,9. Jumlah air yang ditambahkan pada ketiga formulasi food bars didapatkan dari selisih antara nilai kadar air awal formulasi dengan nilai kadar air yang ditentukan dari kurva ISL dengan menggunakan persamaan GAB. Perhitungan jumlah air yang ditambahkan dapat dilihat pada Tabel 6 .

Tabel 6. Perhitungan jumlah air yang ditambahkan pada formula food bars

\begin{tabular}{cccc}
\hline $\begin{array}{c}\text { Formula food } \\
\text { bars }\end{array}$ & $\begin{array}{c}\text { Kadar air awal } \\
\left(\mathrm{g} \mathrm{H}_{2} \mathrm{O} / 50 \mathrm{~g}\right)\end{array}$ & $\begin{array}{c}\text { Kadar air ISL } \\
\left(\mathrm{g} \mathrm{H}_{2} \mathrm{O} / 50 \mathrm{~g}\right)\end{array}$ & $\begin{array}{c}\text { Jumlah air yang } \\
\text { ditambahkan } \\
\left(\mathrm{g} \mathrm{H}_{2} \mathrm{O} / 50 \mathrm{~g}\right)\end{array}$ \\
\hline F1 & 10,4423 & 16,4857 & 6,0433 \\
F2 & 10,4045 & 18,4972 & 8,0927 \\
F3 & 10,7371 & 16,7523 & 6,0152 \\
\hline
\end{tabular}

\section{Sifat Sensoris Food Bars}

Analisis sensoris dengan metode uji kesukaan scoring bertujuan untuk mengetahui tingkat penerimaan panelis terhadap food bars melalui indera penglihatan, pembau dan perasa. Panelis yang digunakan pada uji kesukaan scoring sebanyak 25 orang panelis tidak terlatih.

Food bars pada penelitian ini dengan ukuran $\pm 4 \mathrm{~cm} \mathrm{x} 4$ $\mathrm{cm}$ x $2 \mathrm{~cm}$. Parameter yang diamati dalam uji sensoris adalah warna, aroma, rasa, tekstur dan overall. Penilaian terdiri dari 5 yaitu dari skala nilai 1 (tidak suka), 2 (agak tidak suka), 3 (netral), 4 (agak suka) dan 5 (suka). Hasil analisis sensoris food bars disajikan pada Tabel 7 .

Tabel 7. Sifat sensoris food bars

\begin{tabular}{cccccc}
\hline \multirow{2}{*}{ Formulasi } & \multicolumn{5}{c}{ Parameter } \\
\cline { 2 - 6 } & Warna $^{*}$ & Aroma $^{*}$ & Rasa* $^{*}$ & Tekstur* $^{*}$ & Overall* $^{*}$ \\
\hline F1 & $3,60^{\mathrm{a}}$ & $4,16^{\mathrm{b}}$ & $4,00^{\mathrm{b}}$ & $3,40^{\mathrm{a}}$ & $3,96^{\mathrm{b}}$ \\
F2 & $3,72^{\mathrm{a}}$ & $4,36^{\mathrm{b}}$ & $3,76^{\mathrm{b}}$ & $3,56^{\mathrm{a}}$ & $3,72^{\mathrm{b}}$ \\
F3 & $3,64^{\mathrm{a}}$ & $3,60^{\mathrm{a}}$ & $2,76^{\mathrm{a}}$ & $3,20^{\mathrm{a}}$ & $2,92^{\mathrm{a}}$ \\
\hline
\end{tabular}

Keterangan: Nilai yang diikuti huruf yang berbeda pada kolom yang sama menunjukkan adanya beda nyata pada taraf signifikansi 0,05 .

* 1 = tidak suka; 2 = agak tidak suka; 3 = netral; 4 = agak suka; $5=$ suka

F1 : komposisi tepung millet putih $15 \mathrm{gr}+$ kacang merah $10 \mathrm{gr}$ F2 : komposisi tepung millet putih $12,5 \mathrm{gr}+$ kacang merah $12,5 \mathrm{gr}$ F3: komposisi tepung millet putih $10 \mathrm{gr}+$ kacang merah $15 \mathrm{gr}$

Tabel 7 Menunjukkan bahwa perlakuan F1 (komposisi tepung millet putih $15 \mathrm{gr}+$ kacang merah 10 gr) sebagai formula terpilih dengan nilai rerata tingkat kesukaan tertinggi.

\section{Kandungan Gizi Food Bars Formula Terpilih}

Kandungan gizi food bars pada formula terpilih berdasarkan sifat sensoris disajikan pada Tabel 8 .

Tabel 8. Kandungan gizi food bars terpilih

\begin{tabular}{lll}
\hline Komponen & $\mathrm{g} / \mathrm{bar}$ & \% Total kalori \\
\hline Air $(\%)$ & 16,45 & - \\
Abu $(\%)$ & 1,445 & - \\
Protein $(\mathrm{g})$ & 6,425 & 10,99 \\
Lemak (g) & 9,195 & 35,39 \\
Karbohidrat (g) & 24,7 & 42,26 \\
$\mathrm{a}_{\mathrm{w}}$ & 0,81 & - \\
Kalori (kkal/bar) & 233,80 & - \\
\hline
\end{tabular}

Tabel 8 menunjukkan bahwa kadar air food bars adalah $16,45 \%$. Hal ini telah sesuai dengan syarat kadar air food bars sebagai pangan darurat yaitu 10-40\% (Soekarto, 1979). 
Kadar abu food bars berbahan dasar millet dan tepung kacang merah sebesar 1,445\%. Kadar protein food bars sebesar 6,425 $\mathrm{g} /$ bar atau setara $10,99 \%$ dari total telah memenuhi standard pangan darurat. Menurut Zoumas dkk. (2002), produk pangan darurat mengandung protein sebesar $10-15 \%$ dari total kalori.

Kadar lemak food bars sebesar 9,195 g/bar atau setara dengan 35,39\% dari total kalori dan karbohidrat (metode by difference) sebesar $42,26 \%$ dari total kalori. Hal ini sesuai dengan pendapat Zoumas dkk (2002) yang menyatakan bahwa kandungan pada produk pangan darurat mengandung lemak sebesar 35-45\% dan karbohidrat sebesar 40-50\% dari total kalori.

Dari Tabel 8 dapat dilihat bahwa nilai kadar karbohidrat pada pembuatan food bars berbahan dasar tepung millet putih dan tepung kacang merah sebesar 42,26\% dari total kalori. Menurut Zoumas dkk. (2002), kadar karbohidrat produk pangan darurat harus mengandung karbohidrat 40-50\% dari total kalori. Maka kadar karbohidrat produk food bars dari tepung millet putih dan tepung kacang merah telah memenuhi standar kecukupan gizi pangan darurat.

Kandungan air dalam bahan pangan mempengaruhi daya tahan pangan terhadap serangan mikroba, yang dinyatakan dengan $\mathrm{a}_{\mathrm{w}}$, yaitu jumlah air bebas yang dapat dipergunakan oleh mikroorganisme untuk pertumbuhannya ataupun untuk reaksi kimiawi. Menurut Winarno (1997) berbagai mikroorganisme mempunyai $a_{w}$ minimum agar dapat tumbuh dengan baik. Namun nilai $a_{w}$ juga dapat mempengaruhi berbagai reaksi yang terjadi dalam pangan seperti oksidasi lipid, pencoklatan non-enzimatik, reaksi hidrolitik dan aktivitas enzim.

Nilai $a_{w}$ pada food bars tepung millet putih dan tepung kacang merah adalah 0,81. Menurut Soekarto (1979), syarat food bars yang merupakan pangan semi basah atau intermediate moisture food (IMF) memiliki kadar air 10-40\% dengan nilai $\mathrm{a}_{\mathrm{w}}$ berkisar antara 0,6-0,9.

\section{KESIMPULAN}

Formula pangan darurat berbentuk foodbars dengan formula terpilih dengan formulasi yaitu $15 \mathrm{~g}$ tepung millet putih, $10 \mathrm{~g}$ tepung kacang merah, $2 \mathrm{~g}$ gula halus, $10 \mathrm{~g}$ margarin dan $13 \mathrm{~g}$ susu full cream. Dalam $100 \mathrm{~g}$ food bars terkandung air, abu, protein, lemak, karbohidrat, nilai $\mathrm{a}_{\mathrm{w}}$ dan kalori berturut-turut sebesar 16,45\%, 1,445\%, 10,99\%, $35,39 \%$, karbohidrat $42,26 \%$, a 0,81 dan total kalori 233,80 $\mathrm{kkal} /$ bar telah memenuhi standar pangan darurat.

\section{UCAPAN TERIMA KASIH}

Penulis mengucapkan terima kasih kepada LPPM-UNS yang telah membantu terlaksananya penelitian ini melalui
Program Hibah Dana PNBP UNS Tahun Anggaran 2014 Skim Hibah Unggulan Fakultas dengan nomor kontrak: 501/ UN27.11/PN/2014 tertanggal 16 Juni 2014.

\section{DAFTAR PUSTAKA}

Anonim (1996). Pre-cooked of rice. Journal papers by IRRI scientists. Philiphina Rice Edition: October, 1996.

AOAC (2000). Official Methods of Analysis. Association of Official Analytical Chemists, Washington DC.

Apriyantono, A., Fardiaz, S., Puspitasari, N.L., Yasni, S. dan Budiyanto, S. (1989). Analisis Pangan. IPB Press, Bogor.

Astawan, M. (2009). Sehat dengan Hidangan Kacang dan Biji-bijian. Penebar Swadaya, Depok.

BNBP (2014). Info Bencana: Informasi Kebencanaan Bulanan Teraktual. Pusdatinmas Badan Nasional Penanggulangan Bencana. Edisi Juni 2014.

Labuza, T.P. (1984). Moisture Sorption: Practical Asepticts of Isotherm Measurement and Use. American Association of Cereal Chemists, St. Paul, Minnesota.

Marlin (2009). Sumber Pangan Tanaman Minor. http:// daengnawan.blogspot.com/2009/07/sumber-pangantanaman-minor. html. [16 November 2013].

Marsono, Y., Noor, Z. dan Rahmawati, F. (2003). Pengaruh diet kacang merah terhadap kadar gula darah tikus diabetic induksi alloxan. Jurnal Teknologi $d$ a $n$ Industri Pangan IV(1): 1-6.

Prabowo, B. (2010). Kajian Sifat Fisikokimia Tepung Millet Kuning dan Tepung Millet Merah. Skripsi. Program Studi Teknologi Hasil Pertanian. Fakultas Pertanian. Universitas Sebelas Maret, Surakarta.

Setyaningsih, D., Apriyantono, A. dan Sari, M.P. (2010). Analisis Sensori untuk Industri Pangan dan Agro. IPB Press, Bogor.

Siswanti, dan Ariyantoro, A.R. (2012). Karakterisasi Snack Bar dari Tepung Kacang Merah (Phaseolus vulgaris l.) Pratanak sebagai Alternatif Camilan Penderita Diabetes. Program Studi Teknologi Hasil Pertanian. Universitas Veteran Bangun Nusantara, Sukoharjo.

Soekarto, S.T. (1979). Air Ikatan, Penetapan Kuantitatif dan Penerapannya pada Stabilitas Pangan dan Disain Pangan Semi Basah. Departemen Teknologi Hasil Pertanian Fatemeta Institut Pertanian Bogor, Bogor.

Suyitno, T. (1995). Sifat penyerapan lembab bubuk buah durian dan sirsak. Agritech 16: 5-10. 
Widjanarko, S.B. (2008). Pangan Darurat (Food Bars) Berenergi Tinggi Menggunakan Tepung Komposit (Tepung Gaplek, Tepung Kedelai, Tepung Terigu) dan Tepung Porang (Amorphophallus oncophyllus) atau Konjac Flour. www.simonbwidjanarko.wordpress. com. [2 Januari 2014].

Winarno, F.G. (1997). Kimia Pangan. Gramedia Pustaka Utama, Jakarta.
Zoumas, B.L., Armstrong, L.E., Backstrand, J.R., Chenoweth, W.L., Chinachoti, P., Klein, B.P., Lane, H.W., Marsh, K.S. dan Tolvanen, M. (2002). High-Energy, NutrienDense Emergency Relief Food Product. Food and Nutrition Board: Intitute of Medicine. National Academy Press, Washington DC. 